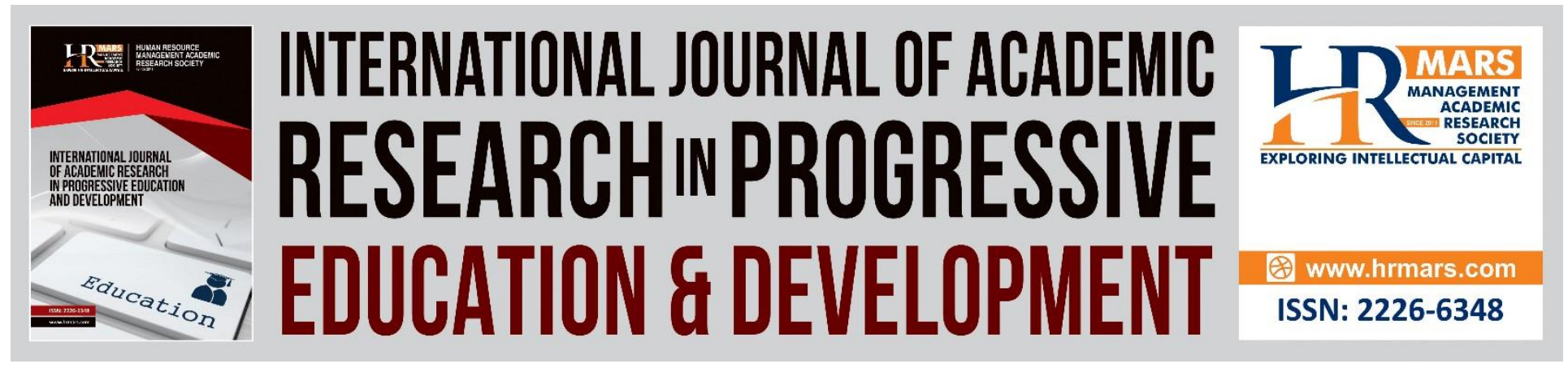

\title{
Undergraduate Students Readiness Towards Online Teaching and Learning during COVID-19
}

Wan Anisha Wan Mohammad, Azlina Mohd Mydin, Rafizah Kechil and Zuraira Libasin

To Link this Article: http://dx.doi.org/10.6007/IJARPED/v10-i2/10129

DOI:10.6007/IJARPED/v10-i2/10129

Received: 03 April 2021, Revised: 08 May 2021, Accepted: 28 May 2021

Published Online: 10 June 2021

In-Text Citation: (Mohammad et al., 2021)

To Cite this Article: Mohammad, W. A. W., Mydin, A. M., Kechil, R., \& Libasin, Z. (2021). Undergraduate Students Readiness Towards Online Teaching and Learning during COVID-19. International Journal of Academic

Research in Progressive Education and Development, 10(2), 474-482.

Copyright: (C) 2021 The Author(s)

Published by Human Resource Management Academic Research Society (www.hrmars.com)

This article is published under the Creative Commons Attribution (CC BY 4.0) license. Anyone may reproduce, distribute, translate and create derivative works of this article (for both commercial and non-commercial purposes), subject to full attribution to the original publication and authors. The full terms of this license may be seen at: http://creativecommons.org/licences/by/4.0/legalcode

Vol. 10(2) 2021, Pg. 474 - 482

http://hrmars.com/index.php/pages/detail/IJARPED

JOURNAL HOMEPAGE

Full Terms \& Conditions of access and use can be found at http://hrmars.com/index.php/pages/detail/publication-ethics 


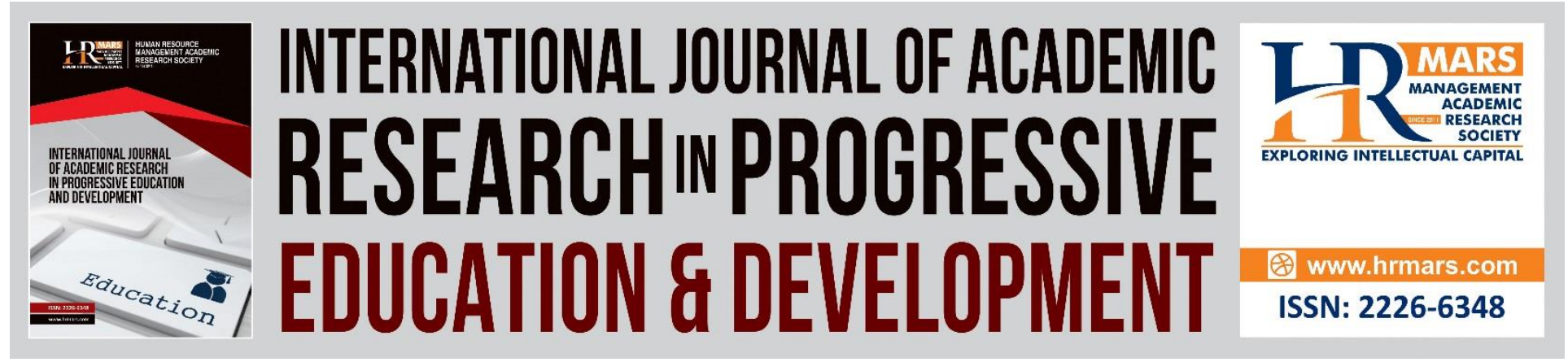

\title{
Undergraduate Students Readiness Towards Online Teaching and Learning during COVID-19
}

\author{
Wan Anisha Wan Mohammad, Azlina Mohd Mydin, Rafizah Kechil \\ and Zuraira Libasin \\ Department of Computer and Mathematical Sciences, UiTM Cawangan Pulau Pinang \\ Malaysia
}

\begin{abstract}
The breakdown of COVID-19 has led to Movement Control Order (MCO) in Malaysia which started on 18 March 2020. This partial lockdown is implemented to prevent COVID-19 pandemic from being overspread throughout Malaysia. MCO has affected many people around the world especially those in the education field. The closure of school and institute of higher education have given a great impact to the students. To make sure that educations are continuously being distributed to students at their own place during MCO, educators have applied online teaching and learning. This paper is done to study undergraduate students' readiness towards online teaching and learning during COVID-19. A survey on students' readiness has been distributed to 191 students from Faculty of Civil Engineering, UiTM Cawangan Pulau Pinang.
\end{abstract}

Keywords: COVID-19, Readiness, Online Learning, Relationship, Undergraduate

\section{Introduction}

Nowadays, online teaching and learning are being implemented to many educational institutions to provide flexible and student-centered learning. Through online teaching and learning, students can obtain education anywhere at anytime. During MCO, students and lecturers are not able to come to work or class and this poses major challenges to them. Due to this uncertainty situation, our education system needs to prepare a fast solution in order to sustain effective teaching and learning during the shutdown besides making sure that students academic performance will remain the same as before (Garcia \& Weiss, 2020).

Since MCO or Movement Control Order is being implemented to prevent the COVID-19 pandemic, educators started to use online teaching and learning to deliver their lectures and assessment to their students. Online teaching and learning or e-learning is the process of transforming and delivering knowledge through the Internet using electronic media. Since students are used to face-to-face or traditional classroom learning, there may be some limitations with the online teaching and learning. An important issue that needs to be identified is the need for determining and maintaining quality education using the new norm. In any higher 
education institution, learning online is not a big issue. However, the student's readiness and access to the technological equipment also needs to be considered (Wahab, 2020)

Many tools can be used to make sure online teaching and learning can be delivered effectively to students. Online platform such as Google Classroom, Google Meet, MS Teams and other Learning Management Systems can be an alternative way to engage student's interaction and learning skills (Stadler-Altmann, 2015).

However, before considering any suitable tools to be used for online teaching and learning, it is very important to understand the students need and limitation. Hence, a survey is done to identify the student's readiness towards online teaching and learning. The scope covers undergraduate students before this way of teaching and learning was being implemented to them. Understanding students' efficacy of online participation and communication characteristics will also help instructors to adjust teaching strategies to enhance students' online learning experiences (Hung et al., 2010).

Online teaching and learning require the teachers and learners to be connected using distance learning (Keegan, 1996). Watson, Winograd, and Kalmon (2004) defined online teaching and learning as education in which instruction and content are being delivered online using network connections. Through online teaching and learning, students can get the knowledge anywhere at any time (Harrell, 2006). Online teaching and learning can also be defined as obtaining knowledge and skills through online and real time learning using various tools supported by the internet technologies (Morrison, 2003).

Limitations of online teaching and learning that has been identified are such as lack of internet access, educators and learners must have a minimum level of computer knowledge, network connection is not 100 percent reliable, inappropriate environment and preparations of online materials (Tubaishat \& Lansari, 2010). To overcome these problems, many institutes of higher education has developed online resources using electronic learning technologies (Deng \& Tavares, 2013; Moore, 2013). The technologies include Learning Management System (LMS) which provide online materials and assessments to students (Islam, 2012).

Warner, Christie and Choy (1998), in their study identified student readiness for online learning was broken down into three key factors which are students' preference in course modality, student competence and confidence in utilizing computer-mediated communication and students' ability to participate in self-directed learning. Many researchers have measure student readiness in online learning through the creation of several online student readiness instruments where student readiness has been examined over the years through a variety of constructs.

The objectives of this study are to identify student's readiness towards online teaching and learning and to determine whether internet accessibility effect students readiness.

\section{Methodology}

Participant

This paper will generally identify student's readiness based on their location during MCO, the internet access at their place, their readiness towards online teaching and learning and limitations during online learning. The participants were undergraduate students from Civil Engineering Program who enrolled in Mathematics and Computer Science courses, offered by 
the Department of Computer \& Mathematical Sciences, Universiti Teknologi MARA Cawangan Pulau Pinang, in semester of March - September 2020. A simple online survey was distributed to 191 students using Google form, and all questions are successfully response.

Instrument and procedure

A simple online survey using google form has been designed to identify student's readiness towards online teaching and learning during the Movement Control Order (MCO) period, which enforced by the government of Malaysia on March 18, 2020. Below are some of the simple questions which are asked regarding student readiness towards online learning.

Question 1: Where are you staying right now during the Movement Control Order?

Question 2: Do you have any Internet access at your place?

Question 3: Readiness for online teaching and learning?

Question 4: Do you have any limitations when accessing any online information?

Question 5: State the limitations when accessing any online information.

The data were analyzed using two statistical software known as Statistical Package for Social Sciences (SPSS) version 21 and Minitab 16.

\section{Results and Discussions}

This study use questionnaires as a means of collecting data. The questionnaire was designed based on the respondent demographic distribution (Allam et al., 2020). 
INTERNATIONAL JOURNAL OF ACADEMIC RESEARCH IN PROGRESSIVE EDUCATION AND

DEVELOPMENT

Vol. 10, No. 2, 2021, E-ISSN: 2226-6348 @ 2021 HRMARS

\section{Table 1. Respondent Demographic Distribution}

$\mathrm{N}$ Category $\quad$ Frequency $\quad$ Percentage \%

1. Centre of Study
a) Faculty of Civil Engineering
200
7.0
b) Faculty of Electrical Engineering
483
17.3
c) Faculty of Mechanical Engineering
427
15.3
d) Faculty of Chemical Engineering
137
4.9
e) Faculty of Pharmacy
215
7.7
f) Faculty of Health Sciences
400
14.3
g) Faculty of Hotel \& Tourism 938
33.5
Management

2. Internet Access at Homeplace:

Yes

2592

92.6

No

208

7.4

3. Available Devices for Online Teaching and Learning:

$\begin{array}{lll}\text { Laptop } & 2176 & 46.92 \\ \text { Desktop } & 97 & 2.10 \\ \text { Tablet } & 77 & 1.66 \\ \text { Smartphone } & 2287 & 49.32\end{array}$

4. Internet Access Facilities:

Broadband

56

1.60

Prepaid phone card

1414

40.32

Public hotspot

107

3.05

Home internet

831

23.70

Mobile hotspot

1099

31.33

5. Data Plan Limits:

Unlimited data

770

27.5

$>20 G B$

134

4.79

5-20GB

558

19.93

$<5 G B$

826

29.50

Not Sure

512

18.28

The findings are represented in both visual and numerical forms. Figure 1 shows the current place where student staying during MCO. Majority students stayed at home during MCO. 


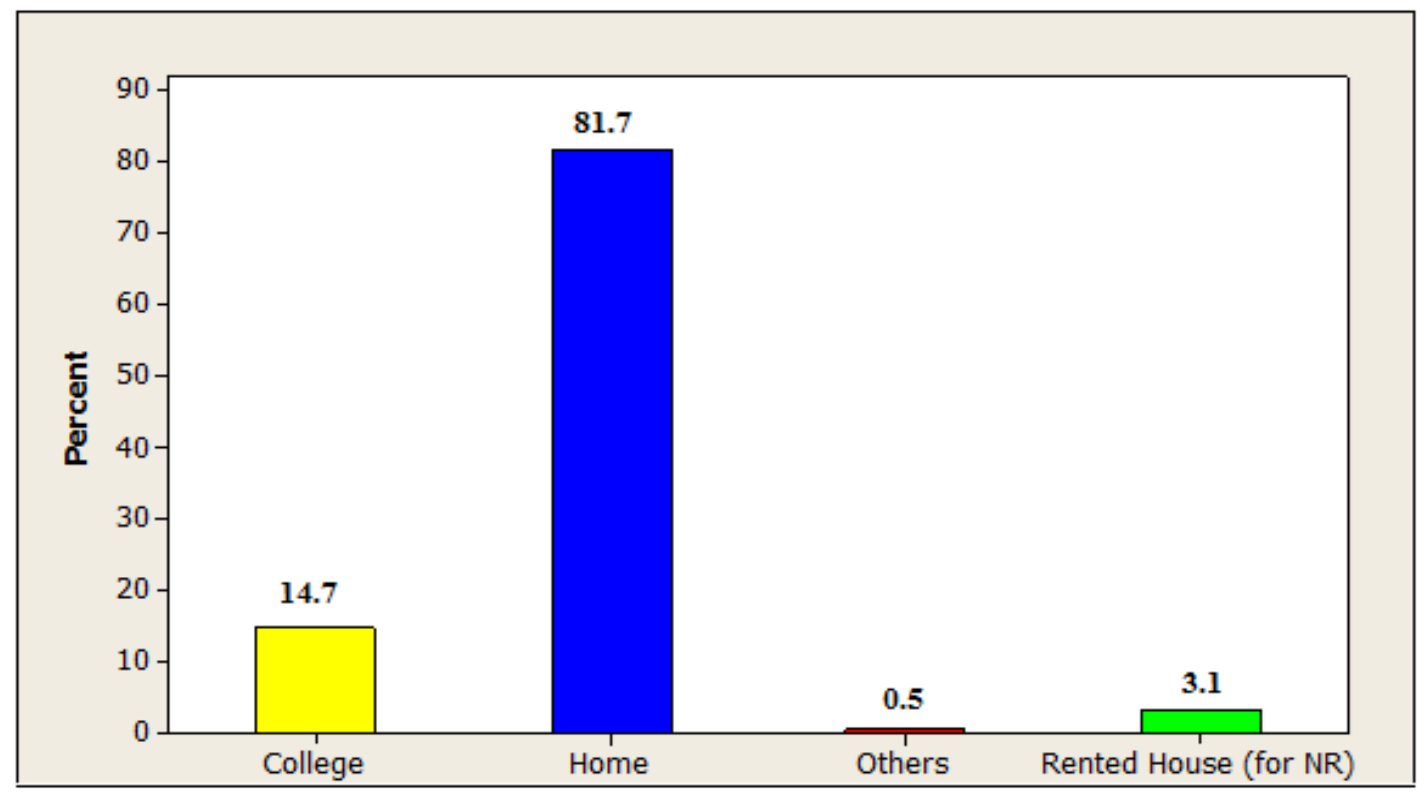

Figure 1. Students location during MCO

Figure 2 illustrates the extension result from Figure 1 by comparing the internet accessibility and the student's location during MCO.

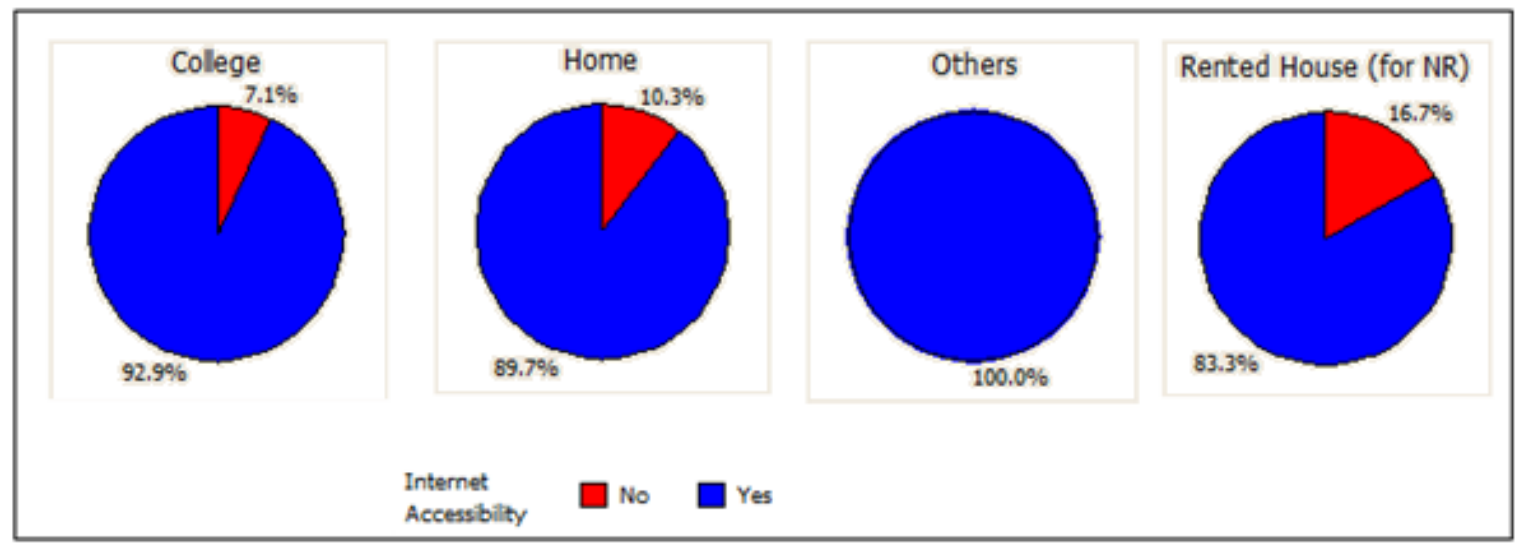

Figure 2. Comparison between the internet accessibility and student's location during MCO

Majority of the students have excellent internet accessibility no matter where they are. Thus, this shows that the internet accessibility is not the major problem for them to skip online classes.

Figure 3 shows the students readiness towards online teaching and learning. Although majority of the students have excellent internet accessibility (Figure 2), but a huge number of students are not ready with online teaching and learning. It shows that internet accessibility is not the main issue of students' readiness in online learning. Muilenberg and Berge (2005) has also identified cost and access to the internet as less important barriers to online learning. 
Vol. 10, No. 2, 2021, E-ISSN: 2226-6348 @ 2021 HRMARS

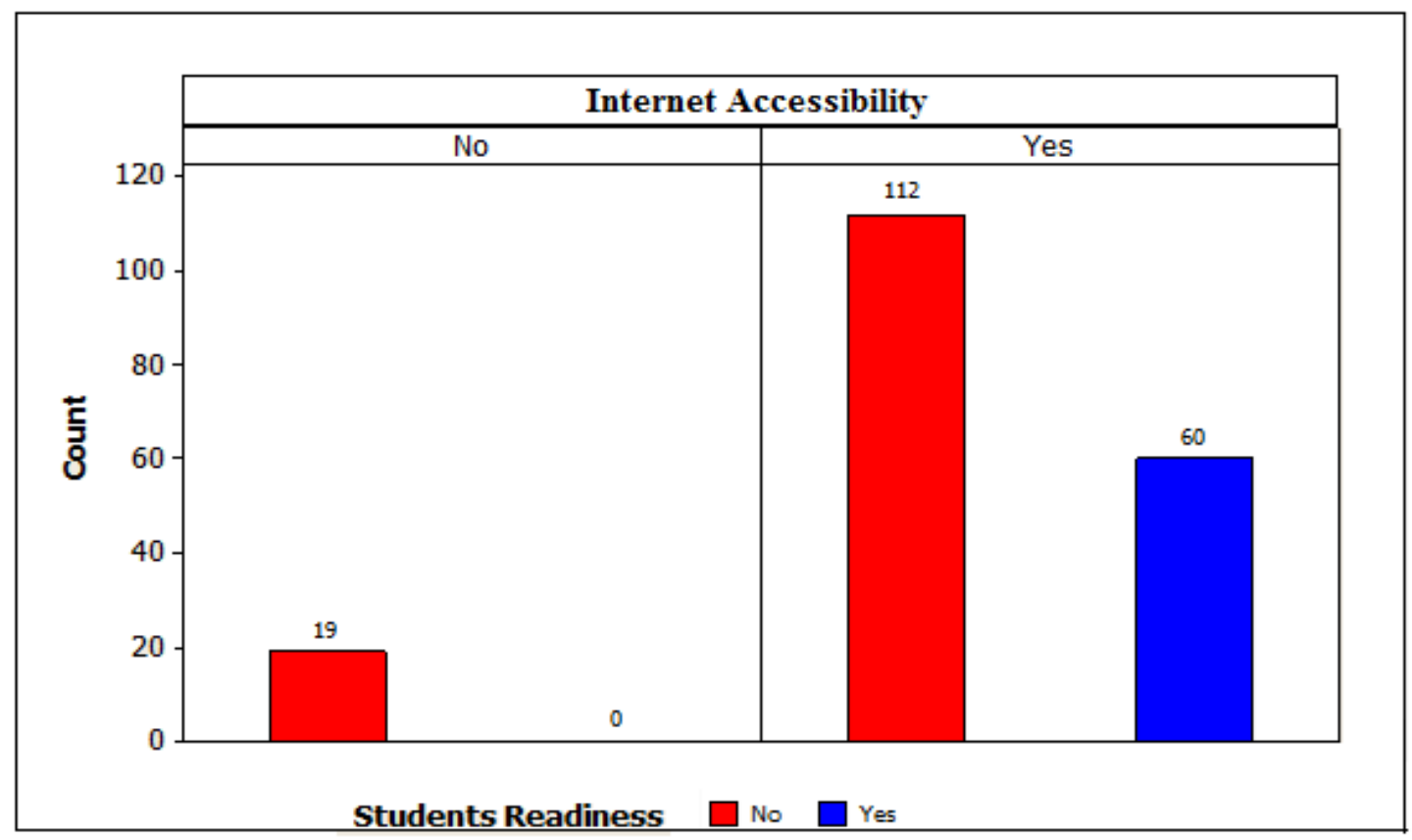

Figure 3. Students readiness towards online teaching and learning

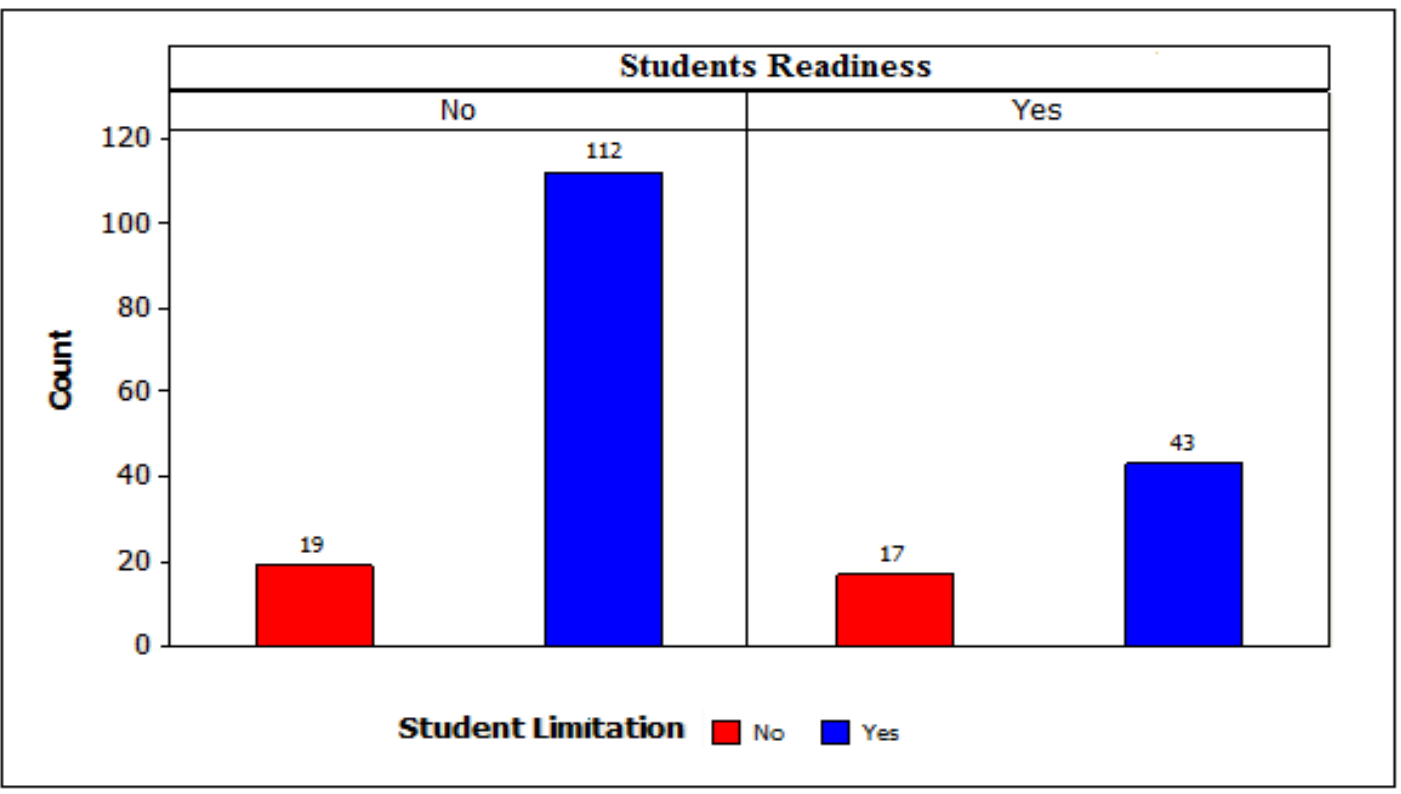

Figure 4. Students limitation on online teaching and learning

Based on figure 4, 81\% students need to face with some limitation when learning through online. About 39\% students are ready to online learning, but more than half of them addressing some limitation in online learning. Majority of them claimed that their internet is slow. This is because during MCO, internet is fully utilized by everyone worldwide.

Based on the results above, there may be other factors that contribute to the student's readiness towards online teaching and learning instead of internet accessibility. Other factors found to contribute to students readiness towards online teaching and learning were tutorials, 
student contribution, the type of instructor, mode of assessment, the content, learning environment, and the resources used (Zaheer et al., 2015). Besides that, students' previous experiences and common media usage behavior (Brandtzæg, 2010; O'Brien \& Verma, 2019), or their skills for using of online communication media (Hong \& Kim, 2018) might impact students' experience and engagement in online learning (Kim et al., 2019).

\section{Conclusion}

Online teaching and learning can be a widely used technology nowadays especially during the COVID-19 pandemic. Instead of going to class and learning face-to-face, online teaching and learning can be an effective way of delivering knowledge to the students. With all the technologies available, most of the students may not have problems with online teaching and learning. However, it is very important to understand not just on the student's readiness but also from the educators' part before online teaching and learning can be fully implemented in any schools or higher institution. Based on the survey, even though internet accessibility is not the main point which lead to student's readiness, there may be other factors that contribute to student's readiness towards online teaching and learning. This will be study in detail in our future paper.

\section{Acknowledgement}

Greatest thanks to all authors who have given high contribution to complete this paper. Thanks to all staffs from the Department of Computer and Mathematical Sciences for supporting us and to our students for spending time to answer the questionnaires given. Finally, thanks to everyone who have helped us in any way.

\section{Corresponding Author}

Wan Anisha Binti Wan Mohammad

Department of Computer and Mathematical Sciences, UiTM Cawangan Pulau Pinang, Malaysia.

Email: wanan122@uitm.edu.my

\section{References}

Brandtzæg, P. B. (2010). Towards a unified Media-User Typology (MUT): A meta-analysis and review of the research literature on media-user typologies. Computers in Human Behavior, 26(5), 940-956.

Deng, L., \& Tavares, N. J. (2013). From Moodle to Facebook: Exploring students' motivation and experiences in online communities. Computers \& Education, 68, 167-176.

Garcia, E., \& Weiss, E. (2020). COVID-19 and student performance, equity, and US education policy: Lessons from pre-pandemic research to inform relief, recovery, and rebuilding. Economic Policy Institute.

Harrell, I. L. (2006). Using student characteristics to predict the persistence of community college students in online courses. The Florida State University. 
INTERNATIONAL JOURNAL OF ACADEMIC RESEARCH IN PROGRESSIVE EDUCATION AND

DEVELOPMENT

Vol. 10, No. 2, 2021, E-ISSN: 2226-6348 @ 2021 HRMARS

Hong, A. J., \& Kim, H. J. (2018). College students' digital readiness for academic engagement (DRAE) scale: Scale development and validation. The Asia-Pacific Education Researcher, 27(4), 303-312.

Hung, M. L., Chou, C., Chen, C. H., \& Own, Z. Y. (2010). Learner readiness for online learning: Scale development and student perceptions. Computers \& Education, 55(3), 1080-1090.

Islam, A. N. (2012). Understanding e-learning system usage outcomes in hybrid courses. In 2012 45th Hawaii International Conference on System Sciences (pp. 118-127). IEEE.

Keegan, D. (1996). Foundations of distance education. Psychology Press.

Kim, H. J., Hong, A. J., \& Song, H. D. (2019). The roles of academic engagement and digital readiness in students' achievements in university e-learning environments. International Journal of Educational Technology in Higher Education, 16(1), 1-18.

Martin, F., Stamper, B., \& Flowers, C. (2020). Examining Student Perception of Readiness for Online Learning: Importance and Confidence. Online Learning, 24(2), 38-58.

Muilenburg, L. Y., \& Berge, Z. L. (2005). Student barriers to online learning: A factor analytic study. Distance education, 26(1), 29-48.

Moore, M. G. (Ed.). (2013). Handbook of distance education. Routledge.

Morrison, D. (2003). E-learning strategies: How to get implementation and delivery right first time. John Wiley \& Sons.

O'Brien, M., \& Verma, R. (2019). How do first year students utilize different lecture resources? Higher Education, 77(1), 155-172.

Warner, D., Christie, G., \& Choy, S. (1998). Readiness of VET clients for flexible delivery including on-line learning. Brisbane: Australian National Training Authority.

Watson, J. F., Winograd, K., \& Kalmon, S. (2004). Keeping pace with K-12 online learning: A snapshot of state-level policy and practice. Learning Point Associates/North Central Regional Educational Laboratory (NCREL).

Stadler-Altmann, U. (2015). The influence of school and classroom space on education. The Routledge international handbook of social psychology of the classroom, 252-262.

Tubaishat, A., \& Lansari, A. (2011). Are students ready to adopt e-learning? A preliminary ereadiness study of a university in the Gulf Region. International Journal of Information and Communication Technology Research, 1(5).

Ali, W. (2020). Online and remote learning in higher education institutes: A necessity in light of COVID-19 pandemic. Higher Education Studies, 10(3), 16-25.

Zaheer, M., Babar, M. E., Gondal, U. H., \& Qadri, M. M. (2015). E-learning and student satisfaction. In Proceedings of the 29th Annual Conference of the Asian Association of Open Universities: New frontiers in ODL (pp. 275-285). 